\title{
MODEL PENGEMBANGAN ANGKUTAN UMUM KAWASAN WISATA DIENG JAWA TENGAH
}

\author{
Titus Hari Setiawan \\ SAPPK \\ Institut Tehnologi Bandung \\ Jln. B, Lb. Siliwangi, Bandung \\ titusharisetiawan@gmail.com
}

\author{
Heru Purboyo Hidayat Putro \\ SAPPK \\ Institut Tehnologi Bandung \\ Jln. B, Lb. Siliwangi, Bandung \\ herupur@pl.itb.ac.id
}

\author{
Pradono \\ SAPPK \\ Institut Tehnologi Bandung \\ Jln. B, Lb. Siliwangi, Bandung \\ onodarp@gmail.com
}

\begin{abstract}
Transportation is one of the important elements in tourism activities. But the tourism sector often does not involve transportation planning in the process of developing a tourism area. This study presents the accessibility provided by the transportation sector in supporting the tourism sector and those related to the provision of public transport and policies in supporting sustainable tourism. The results of this study show that with good tourism and transportation governance, there will be a good balance between economic, social and environmental aspects in tourist areas. Tourists can explore existing attractions without getting lost. With good public transport, limited road capacity can be maximized and finally it can also reduce the negative impact of transportation on natural resources and natural beauty in tourist areas.
\end{abstract}

Keywords: tourism sector, tourism area, public transportation, accessibility

\begin{abstract}
Abstrak
Transportasi merupakan salah satu unsur penting dalam kegiatan pariwisata. Namun sektor pariwisata seringkali tidak melibatkan perencanaan transportasi dalam proses pengembangan suatu kawasan pariwisata. Penelitian ini menyajikan aksesibilitas yang diberikan oleh sektor transportasi dalam mendukung sektor pariwisata dan hal-hal yang berkaitan dengan penyediaan angkutan umum serta kebijakan-kebijakan dalam mendukung pariwisata yang berkelanjutan. Hasil penelitian ini memperlihatkan bahwa dengan adanya tata kelola pariwisata dan transportasi yang baik, akan terjadi keseimbangan yang baik antara aspek ekonomi, sosial, dan lingkungan di kawasan wisata. Wisatawan dapat mengeksplorasi objek wisata yang ada tanpa tersesat. Dengan angkutan umum yang baik, kapasitas jalan yang terbatas dapat dimaksimalkan dan akhirnya juga dapat mengurangi dampak negatif transportasi terhadap sumber-sumber daya alami dan keindahan alam di kawasan wisata.
\end{abstract}

Kata-kata kunci: sektor pariwisata, kawasan pariwisata, angkutan umum, aksesibilitas

\section{PENDAHULUAN}

Dalam perdebatan tentang konsep pariwisata berkelanjutan, kebijakan transportasi sering diabaikan (Høyers, 2000), meskipun merupakan aspek penting bagi perkembangan pariwisata berkelanjutan. Munculnya penelitian tentang perencanaan transportasi yang menunjang pariwisata berkelanjutan (Dubois dan Ceron, 2006) dan penyediaan layanan bus pada destinasi wisata merupakan instrumen penting untuk mencapai tujuan pariwisata keberlanjutan (Guiver, 2012).

Sebagian besar sistem transportasi yang melayani pariwisata mengabaikan unsur keberlanjutan atau penilaian dampak lingkungannya. Proses pengangkutan wisatawan ke, dari, dan di dalam tujuan wisata membangkitkan emisi gas rumah kaca yang tinggi di 
sektor pariwisata (Peeters et al., 2007). Untuk mengurangi dampak negatif transportasi, kunjungan wisatawan sering dikaitkan dengan pilihan moda transportasi pada kunjungan mereka (Lumsdon, 2006).

Pemerintah pusat telah memasukkan Dieng dalam perencanaan yang bersifat nasional. Dalam Rencana Induk Kepariwisataan Nasional 2010-2025, destinasi Borobudur-Yogyakarta menjadi salah satu dari 50 Destinasi Kepariwisataan Nasional. Destinasi ini memiliki 7 Kawasan Pengelolaan Pariwisata, dengan 5 kawasan di wilayah DI Yogyakarta dan 2 wilayah di Jawa Tengah. Jaringan jalan di Kawasan Wisata Dieng dapat dilihat pada Gambar 1.

Masuknya Dieng sebagai kawasan yang dikembangkan akan menarik wisatawan ke Dataran Tinggi Dieng. Potensi pariwisata di Dieng dapat dibagi menjadi 3 macam, yaitu:

1) Potensi alam; yaitu panas bumi (geothermal), pertanian dan buah khas Dieng, serta belerang dari kawah.

2) Potensi budaya; yaitu candi, ruwat rambu gembel, dan seni budaya/festival.

3) Potensi wisata; yaitu kawah, telaga, candi, salju Dieng atau Upas, dan pemandangan alam.

Berdasarkan letaknya, objek-objek wisata di Dataran Tinggi Dieng dikelompokkan menjadi 3 golongan, yaitu:

1) Kawasan Dieng 1; yaitu Telaga Warna, Telaga Pengilon, Gua Semar, Telaga Terus, Kawah Sikidang, dan Taman Arkheologi Dieng (Candi Arjuna, Candi Gatotkaca, Candi Bima).

2) Kawasan Karang Tengah/Dieng 2; yaitu Talaga Swiwi, Kawah Sileri, dan Talaga Merdada.

3) Kawasan Dieng 3; yaitu Sumur Jalatundo, Kawah Candradimuka, dan Gua Jimat.

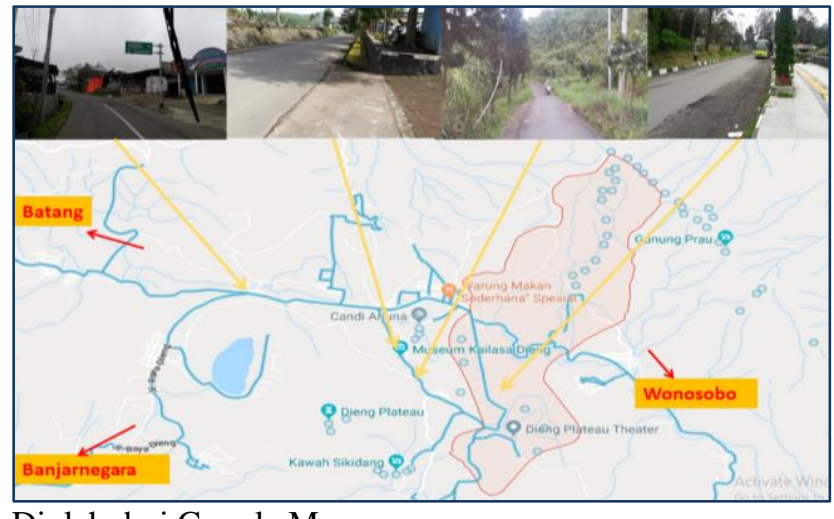

Diolah dari Google Map

Gambar 1 Jaringan Jalan di Kawasan Wisata Dieng

Kajian ini mempelajari pergerakan wisatawan menuju dan dari Kawasan Wisata Dieng, termasuk pergerakan wisatawan pada destinasi yang tersebar di kawasan wisata tersebut dan masalah yang dihadapi wisatawan selama melakukan aktivitas pariwisata. Kemudian akan dicari alternatif dan solusi yang tepat terhadap permasalahan yang ada berdasarkan kajian literatur dan penelitian-penelitian terdahulu. 
Pengambilan data dilakukan melalui survei wawancara terhadap beberapa pihak yang terlibat. Pihak-pihak tersebut adalah Dinas Perhubungan Provinsi Jawa Tengah, Dinas Pariwisata Kabupaten Wonosobo, Dinas Pariwisata Kabupaten Banjarnegara, Petugas Terminal Wisata Mandalawangi Kabupaten Wonosobo, warga setempat, wisatawan yang sedang berkunjung ke kawasan wisata Dieng, dan Pengusaha Angkutan Bus AKDP Wonosobo-Dieng-Batur.

\section{PERGERAKAN DI KA WASAN WISATA DIENG}

\section{Pergerakan Menuju Kawasan Wisata}

Dataran Tinggi Dieng banyak dikunjungi wisatawan, baik domestik maupun mancanegara. Terdapat 3 bandara yang menjadi penghubung terdekat ke kawasan wisata Dieng, yaitu Bandara Ahmad Yani Semarang, Bandara Adi Sutjipto Yogyakarta, dan Bandara Adi Sumarmo Solo (lihat Gambar 2). Selain itu, terdapat 5 stasiun kereta api terdekat yang bisa menjadi akses menuju ke kawasan wisata Dieng, yaitu: Stasiun Kereta Api Poncol dan Stasiun Kereta Api Tawang di Semarang, Stasiun Kereta Api Lempuyangan Yogyakarta, Stasiun Kereta Api Balapan Surakarta, dan Stasiun Kereta Api Kutoarjo (lihat Gambar 3). Terdapat juga beberapa terminal bus yang bisa menjadi akses menuju ke Dieng, yaitu Terminal Purwokerto, Terminal Purbalingga, Terminal Banjarnegara, Terminal Wonosobo, Terminal Temanggung, dan Terminal Magelang (lihat Gambar 4).

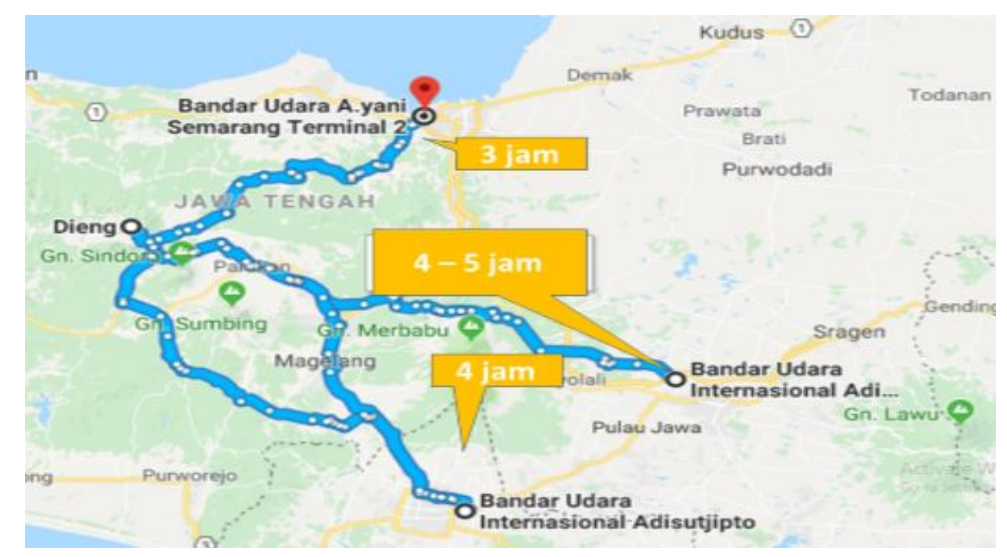

Diolah dari Google Map

Gambar 2 Pergerakan dari Bandara Terdekat

Berbagai tempat penghubung tersedia sebagai akses menuju Kawasan Wisata Dieng yang perlu dikoneksikan dan diintegrasikan dengan berbagai angkutan umum untuk menunjang sektor pariwisata di kawasan wisata tersebut. Adanya konektivitas yang baik akan membuat waktu perjalanan dan waktu tunggu semakin singkat serta mengurangi tenggat perpindahan moda angkutan umum. Akses menuju ke Dieng adalah sebagai berikut: 
1) Lintas Yogyakarta-Magelang-Parakan-Wonosobo-Dieng.

2) Lintas Semarang-Bawen-Temanggung-Parakan-Wonosobo-Dieng.

3) Lintas Purwokerto-Banjarnegara-Karangkobar-Wonoyoso-Batur-Dieng.

4) Lintas Purworejo-Loano-Kertek-Wonosobo-Dieng.

5) Lintas Tegal-Pekalongan-Batang-Bandar-Batur-Dieng.

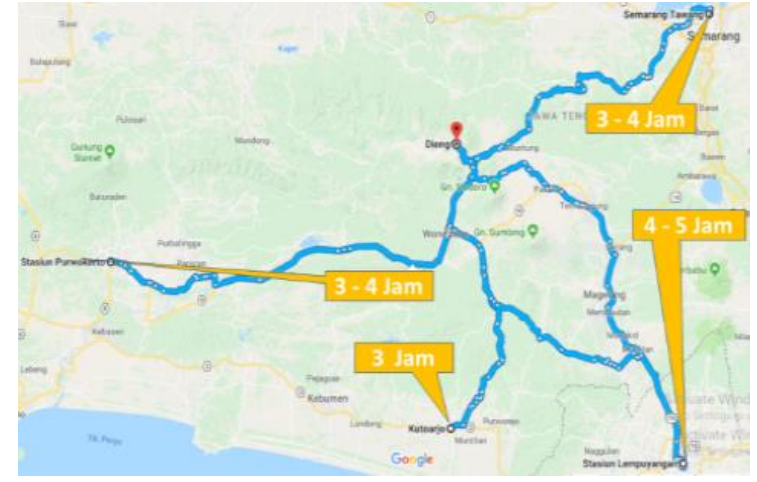

Diolah dari Google Map

Gambar 3 Pergerakan dari Stasiun KA

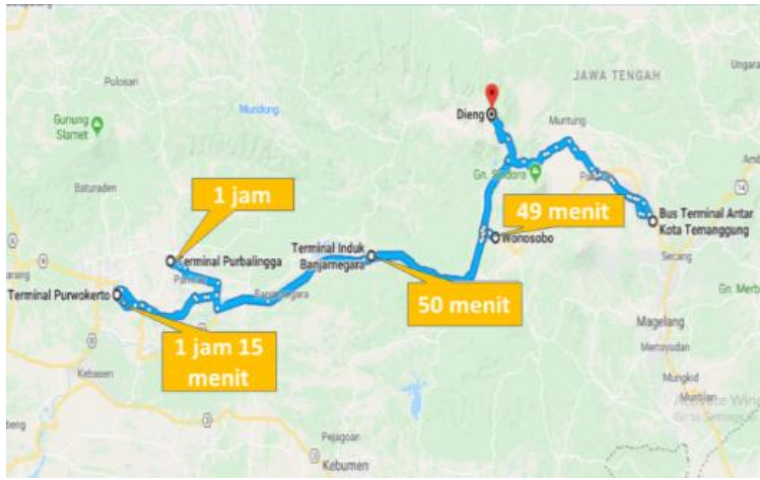

Diolah dari Google Map

Gambar 4 Pergerakan dari Terminal

\section{Pergerakan di Kawasan Wisata}

Pergerakan dengan angkutan umum pada Kawasan Wisata Dieng saat ini dilayani oleh angkutan AKDP kelas ekonomi dengan trayek Wonosobo-Dieng-Batur (Gambar 5). Angkutan ini sebenarnya merupakan angkutan reguler untuk melayani masyarakat dalam rangka pergerakan sehari-hari, seperti bekerja, ke pasar, dan ke sekolah. Sebagian besar wisatawan menggunakan angkutan ini untuk menuju ke objek-objek di Kawasan Wisata Dieng dengan sistem carter. Karena keterbatasan kapasitas jaringan jalan ke Dieng, angkutan AKDP Wonosobo-Dieng-Batur yang digunakan oleh rombongan wisatawan menggunakan bus sedang. Bus besar digunakan untuk melanjutkan perjalanan dari Garung maupun dari Kalianget.

Sebagian besar wisatawan yang berkunjung menggunakan kendaraan pribadi. Hal ini dilakukan oleh wisatawan dengan berbagai destinasi perjalanan, sehingga kunjungan di Kawasan Wisata Dieng hanya dilakukan dalam waktu yang singkat.

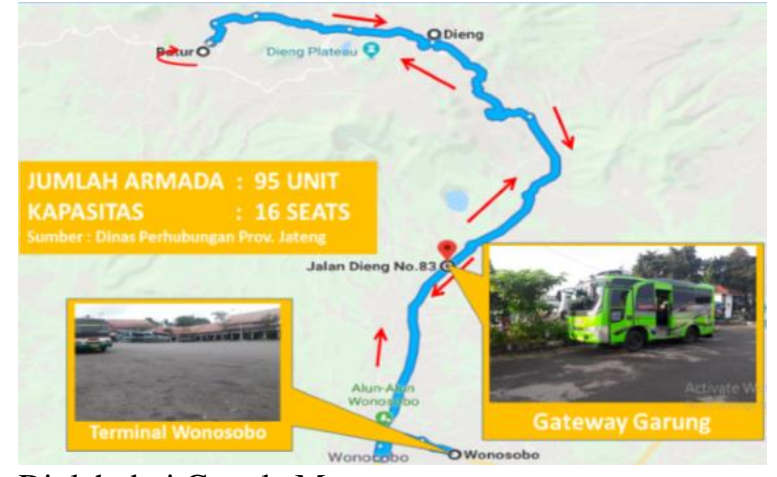

Diolah dari Google Map

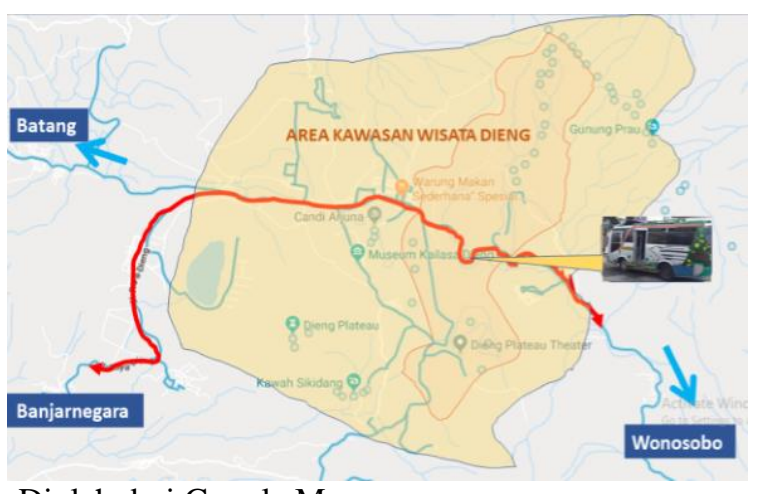

Diolah dari Google Map

Gambar 5 Pergerakan AKDP

Gambar 6 Lintasan Rute AKDP di Dieng 


\section{PERMASALAHAN PERGERAKAN WISATAWAN DI KAWASAN WISATA}

\section{Kapasitas Jaringan Jalan}

Jaringan jalan lokal di kawasan Dataran Tinggi Dieng mempunyai lebar yang bervariasi antara $4 \mathrm{~m}$ sampai dengan $7 \mathrm{~m}$. Jalan utama mempunyai lebar $10 \mathrm{~m}$. Jaringan jalan provinsi melintasi Dataran Tinggi Dieng dari Wonosobo-Dieng, Dieng-Batang, Kebanyakan wisatawan memilih jalur Wonosobo-Dieng karena memiliki rute yang lebih pendek walaupun dengan lebar jalan yang sempit dan berkelok-kelok. Jalur ini dapat ditempuh dalam waktu sekitar 1 jam. Jalur Banjarnegara-Dieng dapat ditempuh dalam waktu sekitar 2 jam, dengan jarak sekitar $50 \mathrm{~km}$, dengan geometrik jalan yang lebih landai daripada jalur Wonosobo-Dieng. Tabel 1 memperlihatkan karakteristik jaringan jalan yang menjadi pintu masuk di kawasan wisata Dieng.

Tabel 1 Data Panjang dan Lebar Jaringan Jalan menuju ke Dieng

\begin{tabular}{clccc}
\hline No. & Akses Jalan & Lebar Jalan & Panjang Jalan & Waktu Tempuh \\
\hline 1. & Wonosobo-Dieng & $(6-8) \mathrm{m}$ & $26 \mathrm{~km}$ & 1 jam \\
2. & Banjarnegara-Dieng & $(6-8) \mathrm{m}$ & $50 \mathrm{~km}$ & 2 jam \\
3. & Batang-Dieng & $(5-6) \mathrm{m}$ & $28 \mathrm{~km}$ & 1 jam 30 menit \\
\hline
\end{tabular}

\section{Pergerakan Kendaraan Pribadi}

Sebagaian besar kunjungan wisatawan ditempuh dengan menggunakan kendaraan pribadi. Pada hari sibuk kunjungan wisatawan, penggunaan kendaraan pribadi sangat tinggi, sehingga mengakibatkan kemacetan lalu lintas, khususnya di titik-titik keramaian yang mempunyai hambatan samping, seperti adanya aktivitas pasar, simpang, dan parkir. Kemacetan umumnya terjadi pada hari-hari sibuk kunjungan wisatawan, yaitu akhir pekan, liburan panjang, dan saat diadakan kegiatan-kegiatan budaya. Pada saat-saat tersebut, waktu tempuh yang biasanya sekitar 1 jam dapat menjadi sekitar 4 jam hingga 5 jam.

Promosi pariwisata yang gencar dilakukan tanpa memperhatikan kapasitas daerah tujuan wisata akan mengakibatkan kerusakan pada objek, sumber daya, atau keindahan alam yang ada. Suasana pedesaan dengan pemandangan alam yang indah, sepi, dan udara yang segar berubah menjadi seperti suasana di kota yang macet, polusi, dan sangat ramai karena ruang di tempat wisata dipenuhi dengan kendaraan. Kapasitas tempat parkir dan tempat istirahat akan penuh dengan kendaraan sehingga kendaraan diparkir pada bahu jalan dan di lapangan-lapangan yang tersedia. Durasi kunjungan wisatawan yang cukup lama akan berdampak pada waktu parkir yang lama, yang mengakibatkan semakin sulitnya untuk mencari ruang parkir.

\section{Konektivitas Angkutan Umum dan Kurangnya Informasi tentang Cara Mengakses Objek Wisata}

Selain dengan moda kendaraan pribadi, kawasan wisata Dieng juga dapat diakses dengan menggunakan angkutan umum. Permasalahan yang terjadi saat ini adalah rendahnya konektivitas antarmoda transportasi pada tempat penghubung yang ada. Tidak tersedianya 
tempat penghubung yang memberikan akses langsung ke Kawasan Wisata Dieng, menyebabkan wisatawan harus berganti moda setidaknya 3 kali atau 4 kali. Sebagai contoh, seseorang yang datang melalui Bandara Ahmad Yani tidak bisa langsung menggunakan bus yang langsung menuju Wonosobo atau Dieng, kecuali dengan angkutan yang sifatnya privat, seperti taksi atau angkutan sewa lainnya. Hal ini menyebabkan biaya perjalanan menjadi sangat tinggi, kecuali jika sifatnya rombongan. Wisatawan harus menuju terminal bus atau agen yang menyediakan angkutan umum menuju ke Wonosobo, dan selanjutnya harus berganti moda lagi dari Wonosobo menuju ke Dieng. Tingkat perpindahan moda tersebut seharusnya bisa dipangkas menjadi 2 kali saja, seperti terlihat pada Gambar 7.

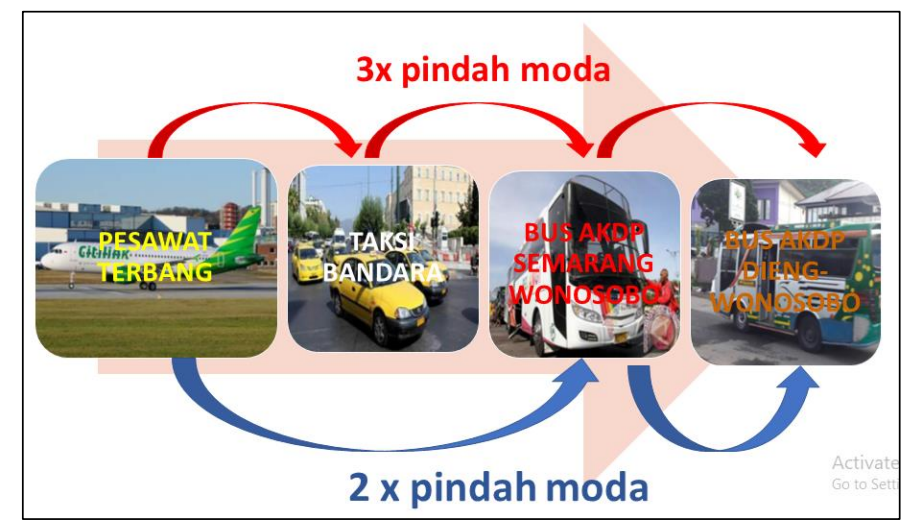

Gambar 7 Konektivitas Antarmoda Angkutan Umum Bandara A.Yani ke Dieng

Keterbatasan kapasitas jalan eksisting juga berakibat pada angkutan yang menggunakan bus besar dan bus sedang yang tidak bisa masuk Kawasan Wisata Dieng. Penumpang bus harus ditransfer dengan menggunakan bus kecil, yang merupakan angkutan AKDP dengan trayek Wonosobo-Dieng-Batur, sehingga sejumlah angkutan AKDP yang seharusnya melayani aktivitas masyarakat setempat, dialokasikan untuk melayani wisatawan. Hal ini mengakibatkan ketidaknyamanan bagi wisatawan karena kendaraan yang digunakan adalah armada reguler kelas ekonomi dan bukan angkutan untuk pariwisata. Selain itu, informasi yang jelas di tempat penghubung atau di angkutan umum tentang pencapaian objek wisata yang dituju masih kurang tersedia.

\section{Mobilitas Wisatawan pada Destinasi}

Mobilitas wisatawan pada destinasi kurang didukung oleh fasilitas sarana dan prasarana yang ada, seperti angkutan umum, fasilitas bersepeda, dan fasilitas pejalan kaki. Hal ini terutama dialami oleh wisatawan yang menginap dan menggunakan angkutan umum yang tersedia. Dari hasil wawancara dengan petugas UPT Dinas Pariwisata Kabupaten Wonosobo diperoleh informasi sebagai berikut:

1) Bus AKDP yang disewa untuk mengantar wisatawan keliling objek wisata menyimpang dari rute yang telah ditetapkan. Sewa bus untuk mengeksplorasi kawasan wisata inti saja, seperti Candi Arjuna, Telaga Warna, Kawah Sikidang, Dieng Plateu Theater, dan Bukit Sikunir, adalah sekitar Rp400.000,00, dan biasanya digunakan oleh wisatawan 
rombongan. Untuk wisatawan yang dalam satu grup hanya ada 2 atau 3 orang saja, harga sewa ini dirasa mahal.

2) Tarif angkutan ojek yang cukup tinggi dan tidak ada aturan yang jelas tentang pentarifan menyebabkan wisatawan seringkali merasa tertipu dengan tarif yang dibayar.

3) Fasilitas berjalan kaki yang sangat minim yang membuat ketidaknyamanan bagi wisatawan

\section{SOLUSI DAN ALTERNATIF}

\section{Model Pembatasan Lalu Lintas}

Beberapa wilayah di Eropa juga memiliki kasus yang mirip dengan Kawasan Wisata Dieng, Jawa Tengah. Sebanyak 82\% pengunjung Taman National Bayericer Wald, Jerman menggunakan mobil. Tingginya tingkat penggunaan kendaraan pribadi mengakibatkan terjadinya kemacetan, polusi, dan kesulitan parkir. Solusi yang diberikan oleh pengelola taman nasional adalah dengan menerapkan pola carrot and stick, yaitu dengan melakukan pembatasan armada dan pemberian insentif berupa angkutan umum gratis untuk mengeksplorasi jalan-jalan yang ada di taman nasional. Penerapan ini berhasil dan mendapat apresiasi yang baik dari wisatawan dan penduduk setempat. Namun ada juga penolakan dari berbagai kalangan, seperti pebisnis lokal dan sebagian penduduk setempat yang aksesnya ditutup (Holding dan Kreutner, 1998).

\section{Angkutan Umum Kawasan Wisata}

Suatu cara untuk mengurangi emisi transportasi di bidang pariwisata adalah mendorong penggunaan moda yang ramah lingkungan, seperti moda kendaraan tidak bermotor dan angkutan umum. Di beberapa taman nasional di Eropa dan Amerika Serikat, angkutan umum menjadi solusi dan bagian pengalaman wisatawan dalam berekreasi di daerah wisata dengan daya tarik tersendiri.

\section{Gate Management}

Langkah-langkah yang harus diambil untuk memengaruhi perilaku pengunjung tidak cukup dengan pembatasan akses jalan dan biaya jalan, tetapi juga memerlukan tindakan lain, seperti penyediaan transportasi umum dan fasilitas pejalan kaki. Pembatasan jalan yang memengaruhi akses pengunjung dapat menimbulkan banyak tentangan dari masyarakat (Holding, 2001). Diperlukan pengembangan gateway management dengan berbagai fasilitas yang dapat memengaruhi orang untuk meninggalkan mobil mereka di sana, dan berkeliling daerah destinasi wisata dengan cara lain, seperti naik angkutan umum, bersepeda, dan berjalan kaki tanpa membatasi akses.

\section{Sistem Transportasi Cerdas}

Sistem transportasi cerdas (Intelligent Transport System, ITS) telah dikembangkan di Rocky Mountain National Park dan Estes Park, Amerika Serikat, untuk menyediakan 
informasi yang bersifat real time tentang lalu lintas kendaraan, kondisi parkir, jadwal bus, dan tingkat kunjungan di sepanjang jalan tertentu. ITS bertujuan untuk menarik pengunjung untuk menggunakan sistem angkutan umum sesuai dengan tujuan manajemen pengunjung. Penumpang bus mendukung sistem angkutan umum dan pemilik bisnis lokal mencatat bahwa tempat parkir di gateway lebih sering dipakai ketika bus tersebut beroperasi (Brennan et al., 2002).

\section{Dampak terhadap Ekonomi Lokal}

Agar kebijakan transportasi di kawasan wisata dapat berhasil, perlu ada tujuantujuan (goal) lain yang akan dicapai, sehingga kebijakan tersebut mendapat dukungan masyarakat lokal. Intinya adalah bahwa tujuan-tujuan yang ingin dicapai tersebut dapat memberikan manfaat secara ekonomi kepada masyarakat lokal (Dunning, 2005).

\section{Model Pengembangan Mobilitas di Kawasan Wisata}

Beberapa alternatif untuk pemecahan masalah transportasi di Kawasan Wisata diusulkan pada studi ini. Alternatif-alternatif tersebut adalah penutupan akses kendaraan pribadi, manajemen gateway pada titik Kalianget, Batur, dan perbatasan Kabupaten Batang, angkutan umum alternatif atau wajib, serta pengembangan sistem parkir dan ITS. Selain itu juga, harus melibatkan berbagai stakeholder terkait.

Alternatif pertama merupakan suatu model sistem transportasi yang diterapkan pada hari sibuk kunjungan wisatawan, yaitu hari libur nasional, hari ketika diadakan event berskala besar, atau long weekend. Pada model ini diusulkan untuk dilakukan:

(a) Penutupan akses jalan untuk kendaraan pribadi, kecuali kendaraan warga setempat.

(b) Penataan rute, peningkatan kualitas pelayanan, dan pemberlakuan angkutan umum wajib sebagai satu-satunya alat transportasi untuk mengeksplorasi kawasan wisata yang dikombinasi dengan berjalan kaki dan bersepeda.

(c) Penggunaan gateway sebagai tempat parkir wajib kendaraan pribadi dan tempat wisata alternatif bagi pengunjung yang tidak masuk kawasan wisata, dan tempat alternatif bagi bisnis lokal yang terdampak oleh penutupan akses jalan untuk kendaraan pribadi.

(d) Penutupan tempat parkir untuk kendaraan pribadi pada destinasi wisata.

(e) Penggunaan ITS untuk memberi informasi kondisi kemacetan, ketersediaan parkir, biaya parkir yang tinggi pada hari sibuk kunjungan wisata kepada pengunjung, tempat wisata alternatif lainnya, serta penutupan akses jalan untuk kendaraan pribadi di kawasan wisata dan identifikasi kendaraan pribadi mili warga setempat supaya tetap bisa masuk kawasan wisata.

Alternatif kedua merupakan model sistem transportasi yang diterapkan pada harihari setengah sibuk kunjungan wisatawan. Hari setengah sibuk ini adalah hari biasa namun kunjungan wisatawan cukup ramai atau hari liburan sekolah. Pada hari-hari ini diusulkan hal-hal sebagai berikut:

(a) Pembukaan akses jalan untuk semua jenis kendaraan. 
(b) Penataan angkutan umum sebagai alat transportasi alternatif untuk mengeksplorasi kawasan wisata yang dikombinasikan dengan berjalan kaki dan bersepeda.

(c) Pemanfaatan gateway sebagai tempat parkir kendaraan pribadi dan sebagai tempat wisata alternatif bagi pengunjung, dengan fasilitas yang lengkap untuk menarik pengunjung menggunakan angkutan umum.

(d) Penerapan biaya parkir progresif yang tinggi pada destinasi.

(e) Penggunaan ITS untuk memberi informasi kondisi jalan pada destinasi, kapasitas parkir, biaya parkir yang tinggi, destinasi wisata yang ada, angkutan umum yang dapat memberi pengalaman khusus kepada wisatawan pada saat mengeksplorasi destinasi, dan informasi tentang objek-objek wisata yang dikunjungi.

Alternatif ketiga merupakan model sistem transportasi untuk hari-hari tidak sibuk kunjungan wisatawan atau hari biasa. Pada alternatif ini diusulkan untuk dilakukan:

(a) Pembukaan akses jalan untuk semua jenis kendaraan.

(b) Penataan rute angkutan umum dan peningkatan kualitas pelayanan angkutan umum sebagai alat transportasi alternatif yang menarik dan dapat memberikan pengalaman khusus yang dikombinasikan dengan berjalan kaki dan bersepeda.

(c) Pemanfaatan gateway sebagai tempat parkir kendaraan pribadi dan tempat wisata alternatif bagi pengunjung.

(d) Penerapan biaya parkir progresif yang tinggi pada destinasi.

(e) Pemanfaatan ITS yang berfungsi menginformasikan kondisi jalan pada destinasi, kapasitas parkir, biaya parkir yang tinggi, destinasi wisata yang ada, angkutan umum yang dapat memberikan pengalaman khusus pada saat mengeksplorasi destinasi, dan informasi tentang objek-objek wisata yang dikunjungi.

\section{KESIMPULAN}

Angkutan umum berperan penting dalam mobilitas pariwisata berkelanjutan. Berbagai model dikembangkan dalam rangka menjaga keseimbangan, baik dari sisi lingkungan, ekonomi, maupun sosial. Kombinasi kebijakan pengaturan pada gateway dengan meyediakan fasilitas parkir, penerapan biaya parkir yang tinggi pada zona inti, pembatasan kendaraan pribadi, penyediaan sistem angkutan umum berkualitas tinggi, dan pemanfaatan ITS diharapkan akan mampu untuk: (1) mengurangi penggunaan kendaraan pribadi, (2) memberikan informasi real time tentang kondisi arus lalu lintas, kapasitas parkir destinasi, angkutan umum, dan cara mengakses destinasi wisata, (3) meningkatkan kapasitas dan mobilitas wisatawan pada destinasi wisata, (4) meningkatkan konektivitas dan peralihan antarmoda angkutan umum, (5) mengurangi dampak negatif terhadap sumber daya alam dan lingkungan, (6) memberikan manfaat bagi komunitas lokal, bisnis lokal, dan masyarakat setempat; dan (7) mendapat dukungan dari para pemangku kepentingan terkait. 


\section{DAFTAR PUSTAKA}

Brennan, R., Edwards, M., dan Daigle, J.J. 2002. Private Business Perceptions of Transportation Issues and the Island Explorer Bus System at Acadia National Park. Proceedings of the 2001 Northeastern Recreation Research Symposium. Northeastern Research Station. Newton Square, PA.

Dubois, G. dan Ceron, J.P. 2006. Tourism and Climate Change: Proposals for a Research Agenda. Journal of Sustainable Tourism, 14 (4): 399-415.

Dunning, A.E. 2005. Impacts of Transit in National Parks and Gateway Communities. Transportation Research Record: Journal of the Transportation Research Board, 1931 (1): 129-136.

Guiver, J. 2012. How Can You Estimate the Value of A Bus Service? Evaluating Buses in Tourist Areas. Association of European Transport Conference, Glasgow, PTRC.

Holding dan Kreutner. 1998. Achieving a Balance Between "Carrots" and "Sticks" for Traffic in National Parks: The Bayerischer Wald Project. Transport Policy, 5 (3): 175-183.

Holding, D.M. 2001. The Sanfte Mobilitaet Project: Achieving Reduced Car-dependence in European Resort Areas. Tourism Management, 22 (4): 411-417.

Høyers, K. 2000. Sustainable Tourism or Sustainable Mobility? The Norvegian Case. Journal of Sustainable Tourism, 8 (2): 147-160.

Lumsdon, L. 2006. Factors Affecting the Design of Tourism Bus Services. Annals of Tourism Research, 33 (3): 748-766.

Peeters, P., Szimba, E., dan Duijnisveld, M. 2007. Major Environmental Impacts of European Tourist Transport. Journal of Transport Geography, 15: 83-93.

Pemerintah Republik Indonesia. 2011. Peraturan Pemerintah Nomor 50 Tahun 2011 tentang Rencana Induk Kepariwisataan Nasional 2010-2025. Jakarta. 